\title{
Phytochemical and Biological Activity Studies of Tinospora crispa Stem
}

\author{
Mariam Rahman, Md. Hasanur Rahman and Tofail Ahmad Chowdhury** \\ Department of Chemistry, University of Dhaka, Dhaka-1000, Bangladesh.
}

(Received : 21 September 2020; Accepted : 4 October 2020)

\begin{abstract}
Three compounds namely, tinosporol A, 8-methoxy palmatine and callecdysterol $\mathrm{C}$ were isolated from the methanol extract of the stem of Tinospora crispa. Biological activities of different partitionates of the parent extract was also evaluated. Antimicrobial screening of different partitionates was carried out against sixteen different microorganisms and only nhexane fraction exhibited significant zone of inhibition against Staphylococcus aureus $(9 \mathrm{~mm})$, Shigella boydii $(9 \mathrm{~mm})$, Shigella dysenteriae $(9 \mathrm{~mm})$, Candida albicans $(10 \mathrm{~mm})$ and Aspergillus niger $(10 \mathrm{~mm})$. The crude methanol extract showed the highest general toxicity with $\mathrm{LC}_{50}$ values of $57.14 \mu \mathrm{g} / \mathrm{mL}$ against brine shrimp lethality bioassay.The total antioxidant capacity of aqueous fraction was found to be $61.61 \mathrm{mg}$ as ascorbic acid equivalentper gram of plant extract.The antioxidant activity of DCM fraction revealed the highest activity having $\mathrm{IC}_{50}$ values $54.74 \mu \mathrm{g} / \mathrm{mL}$. No significant cytotoxicity was observed on both HeLa and Vero cell lines.
\end{abstract}

Keywords: Secondary metabolites, Antimicrobial, Lethality bioassay, Antioxidant, Cytotoxicity.

\section{Introduction}

Plants produce a wide range of secondary metabolites, making them an excellent source of various assorted kinds of medicines ${ }^{1}$. T. crispa (Family: Menispermaceae) is a well-known medicinal plant for its versatile pharmaceutical significances due to the presence of various phytoactive compounds ${ }^{2,3}$. Phytochemical analyses of T. crispa revealed the presence of alkaloids ${ }^{4}$, flavonoids, and flavone glycosides, triterpenes, diterpenes and diterpene glycosides, cis-clerodane-type furanoditerpenoids ${ }^{5}$, lactones, sterols, lignans, and nucleosides ${ }^{6}$. It was reproted that the crude extracts and isolated compounds of T. crispa possessed a broad range of pharmacological activities such as antiinflammatory ${ }^{7}$, antioxidant ${ }^{8}$, immune-modulatory ${ }^{9}$, cytotoxic ${ }^{10}$, antimalarial $^{11}$, cardio-protective ${ }^{12}$ and anti-diabetic activities ${ }^{13}$.

The paper reports the isolation of three known compounds and biological activities of different extracts of the stems of T. crispa of the variety from Bangladesh.

\section{Experimental}

\section{Collection of sample}

The stems of the plant were collected from Sylhet, Bangladesh and taxonomic identification was made by the renowned plant taxonomist Professor Dr. Mohammad Zashim Uddin, Department of Botany, University of Dhaka. The collected stems were dried and crushed into powder.

\section{Phytochemical screening}

Phytochemical screening was carried out using standard procedure $^{14}$ for identifying the chemical constituents. The presence of phytochemicals such as tannins, phlabotannins, saponins, flavonoids, steroids, terpenoids and alkaloids were detected.

\section{Extraction and Isolation}

The dried powder (500 g) of T. crispa stems were extracted with methanol and partitioned with n-hexane and fractionation of methanol extract was done with dichloromethane (DCM) and ethyl acetate (EtOAc).The extracts were separately concentrated to dry mass using rotary vacuum evaporator at $40^{\circ} \mathrm{C}$ under reduced pressure. DCM extract $(3.25 \mathrm{~g})$ and EtOAc extract $(4.65 \mathrm{~g})$ were subjected to column chromatography and 15 fractions (P-1 to P-15) were obtained from the TLC study. The fraction P-5 $(\sim 40 \mathrm{mg})$ showed single spot with tailing and was subjected to preparative thin layer chromatography (PTLC) and a white crystalline compound was obtained which was labeled as $\mathbf{3}(\sim 4.5 \mathrm{mg})$. The fraction P7 appeared to contain two spots and was subjected to sub column. One of the fraction was found with single spot under TLC and yielded white powdered compound after washing with solvent (1 5mg). The fraction P-9 gave with two spots on TLC and was subjected to sub-column, and finally a single yellow crystalline compound was obtained $2(\sim 4.5 \mathrm{mg})$.

\section{Biological activity screening}

Freshly prepared stem powder was extracted successively with n-hexane (HEX), dichloromethane (DCM), ethyl acetate (EA) and methanol (ME) at room temperature. All the extracts were evaporated to dryness and used for antimicrobial activity screening, brine shrimp lethality bioassay, cytotoxicity assay on cancer cell lines and determination of total antioxidant capacity using their individual standard procedures ${ }^{15-19}$.

Cytotoxicity assay was examined against HeLa cell line (a human cervical carcinoma cell) and Vero cell line (kidney epithelial cells extracted from an African green monkey) in Center for Advanced Research (CARS), University of Dhaka ${ }^{17}$.

\section{Results and Discussion}

Three compounds (1-3) were isolated from the methanol extract of the stem of $T$. crispa by column and preparative thin layer chromatography. The compound-1 $(\sim 5 \mathrm{mg})$ was a white powdered solid having $\mathrm{R}_{\mathrm{f}}$ value 0.80 (50\%DCM: $50 \%$ EtOAc). It was soluble in DCM. The ${ }^{1} \mathrm{H}-\mathrm{NMR}$ spectrum (400 $\mathrm{MHz}, \mathrm{CDCl}_{3}$ ) of compound-1 showed peaks at $\delta 1.94,2.30$, 7.06, 5.57, 2.23, 2.95, 1.45, 1.63, 4.85, 6.07, 6.25, 1.34, 1.26, 
$3.74 \mathrm{ppm}$. The presence of one sharp triplet signal at $\delta 7.04$ is for olefinic bond which might be for the proton at C-3. The signals at $\delta 5.94$ and $6.25 \mathrm{ppm}$ for protons of C-14, C-16, respectively indicated the existence of furan ring (C-13-C$16)^{20}$. Again there was carbonyl groups (C-18 and C-15), and two angular methyl groups (C-19 and C-20). The spectra also suggested the presence of two $\mathrm{sp}^{3}$-hybridized quaternary carbons (C-5 and C-9), two $\mathrm{sp}^{3}$-hybridized methines (C-6, C8). The spectra showed signals attributed to four $\mathrm{sp}^{3}$ hybridized methylenes (C-1, C-2, C-7, and C-11) and two oxygenated methine groups (C-6 and $\mathrm{C}-12$ and $\mathrm{C}-16)$. The 13C-NMR spectrum (100 $\mathrm{MHz}, \mathrm{CDCl}_{3}$ ) of compound-1 showed main chemical shift at $\delta 177.4,173.5,170.50,166.5$, 142.6, 134.0,117.5, 97.3, 83.3 , 68.2, 51.8, 51.0, 43.8, 42.5, 38.7, 36.2, 28.1 26.9, 23.4, 19.3 and $17.0 \mathrm{ppm}$. The ${ }^{1} \mathrm{H}$ and ${ }^{13} \mathrm{C}$-NMR spectra data of the compound-1 was compared with reported and comparing the reported value and found identical with tinosporol $\mathrm{A}^{20}$.

The compound-2 ( 4.5mg) was a light yellow crystalline solid having $\mathrm{R}_{\mathrm{f}}$ value 0.60 (in 60\% DCM: $40 \%$ EtOAc) and soluble in dichloromethane. The ${ }^{1} \mathrm{H}-\mathrm{NMR}$ spectrum $(400$ $\mathrm{MHz}, \mathrm{CDCl}_{3}$ ) of compound-2 showed signals at $\delta 7.23$, $6.96,6.87,6.57,6.17,6.14,3.94,3.90,3.88,3.60,3.50$, 2.99 and $2.88 \mathrm{ppm}$. Here peaks at $\delta 7.23,6.65,6.96,6.87$ ppm due to presence of hydrogens attached to aromatic ring at position $\mathrm{H}-1, \mathrm{H}-4, \mathrm{H}-11, \mathrm{H}-12$ and at $\delta 6.14 \mathrm{ppm}$ for $\mathrm{H}-$ 13 due to presence of double bond between C-13 and C13a. The signals at $\delta 3.94,3.90,2.99,3.94,3.88 \mathrm{ppm}$ was observed due to presence of five -OMe groups. The 13CNMR spectrum (100 MHz, $\mathrm{CDCl}_{3}$ ) of compound-2 showed main chemical shift at $\delta 150.2,147.8,147.4,146.7,136.2$, $134.2,128.8,126.9, \quad 120.1, \quad 118.0,114.7, \quad 109.6, \quad 106.6$, 94.7,83.9, 60.4, 56.4, 55.9, 55.6 54.7, 51.9 and $29.6 \mathrm{ppm}$. Compound-2 showed the presence of 22 carbons. The signals at $\delta 150.2,147.8,147.4,146.7,134.2,128.8,126.9$, $120.1,118.0,114.7,109.6$ and $106.6 \mathrm{ppm}$ for aromatic carbon atoms. The signals at $\delta 94.7$ and $136.2 \mathrm{ppm}$ for $\mathrm{C}-13$ and $\mathrm{C}-13 \mathrm{a}$ was due to the presence of $\mathrm{C}=\mathrm{C}$ bond between $\mathrm{C}-13$ and $\mathrm{C}-13 \mathrm{a}$. Five signals at $\delta 60.4,56.4,55.9,55.6$ and $54.7 \mathrm{ppm}$ revealed the presence of five -OMe groups and at $\delta 51.9$ and $29.6 \mathrm{ppm}$ were due to the presence of two methylene carbons at C-6 and C-5 respectively. The signal at $\delta 83.94$ showed the presence of an oxymethine carbon at $\mathrm{C}$-8.From the spectral analysis $\left({ }^{1} \mathrm{H}-\mathrm{NMR}\right.$ and $\left.{ }^{13} \mathrm{C}-\mathrm{NMR}\right)$ data of the compound-2 and comparing the reported value of 8-methoxy palmatine ${ }^{21}$, the structure of compound was confirmed as 8-Methoxy palmatine.

The compound-3 ( 4.5mg) was a colorless crystalline solid having $\mathrm{R}_{\mathrm{f}}$ value 0.80 (in $90 \%$ DCM: $10 \%$ EtOAc). It was soluble in dichloromethane. The ${ }^{1} \mathrm{H}-\mathrm{NMR}$ spectrum $(400$ $\mathrm{MHz}, \mathrm{CDCl}_{3}$ ) of compound-3 showed signals at $\delta \quad 0.86$, $1.24,1.75,1.85,2.22,2.24,2.35,3.85,3.86,4.17,5.67,6.27$ $\mathrm{ppm}$. The compound-3 had two singlet signals at $\delta 0.85$ and $1.24 \mathrm{ppm}$ typical for the presence of methyl protons at C-18 and $\mathrm{C}-19$ respectively. The spectrum had multiplet at $\delta 3.85$, 3.86 and $4.15 \mathrm{ppm}$ indicative of the presence of oxymethine protons at C-2, C-3 and C-17 respectively. Two signals appeared at $\delta 5.67$ and $6.27 \mathrm{ppm}$ for olefinic protons at C-7 and C-11 respectively. The other signals of the spectrum between $\delta 1.50$ to 2.35 due to presence different methylene ($\left.\mathrm{CH}_{2}-\right)$ and methine (>CH-) protons.The 13C-NMR spectrum $\left(100 \mathrm{MHz}, \mathrm{CDCl}_{3}\right)$ of compound-3 gave signals at $\delta$ 206.1, 155.7, 136.2, 134.1, 118.0, 83.9, 79.0, 68.7, 67.2, 51.6, 48.3, 42.3, 38.2, 35.8, 35.1, 29.7, 31.8, 29.5, $16.1 \mathrm{ppm}$. The spectrum showed the presence of 19 carbons. Among them 5 signals were assignable to $\mathrm{sp}^{2}$ hybridized carbons, 2 signals to methyl carbons, 5 signals to methylene carbons, 5 signals to methine carbons and 2 signals to quaternary carbons. The signalsat $\delta 118.0,155.7,136.2,134.1 \mathrm{ppm}$ were due to presence of olefinic carbons. The signals at $\delta 42.3$, $48.3 \mathrm{ppm}$ were due to presence of two quaternary carbons. The signals at $\delta 16.1,31.8 \mathrm{ppm}$ were due to presence of two methyl carbons and signals at $\delta 38.2,35.8,35.1,29.7,29.5$ ppm were due to presence of five methylene carbons. Signals at $\delta 68.7,67.2,51.6 \mathrm{ppm}$ were due to presence of methine carbons.

The ${ }^{1} \mathrm{H}$ and ${ }^{13} \mathrm{C}$-NMR spectra data of the compound-3 was compared with reported value and found identical with spectral data of callecdysterol $\mathrm{C}^{22}$.
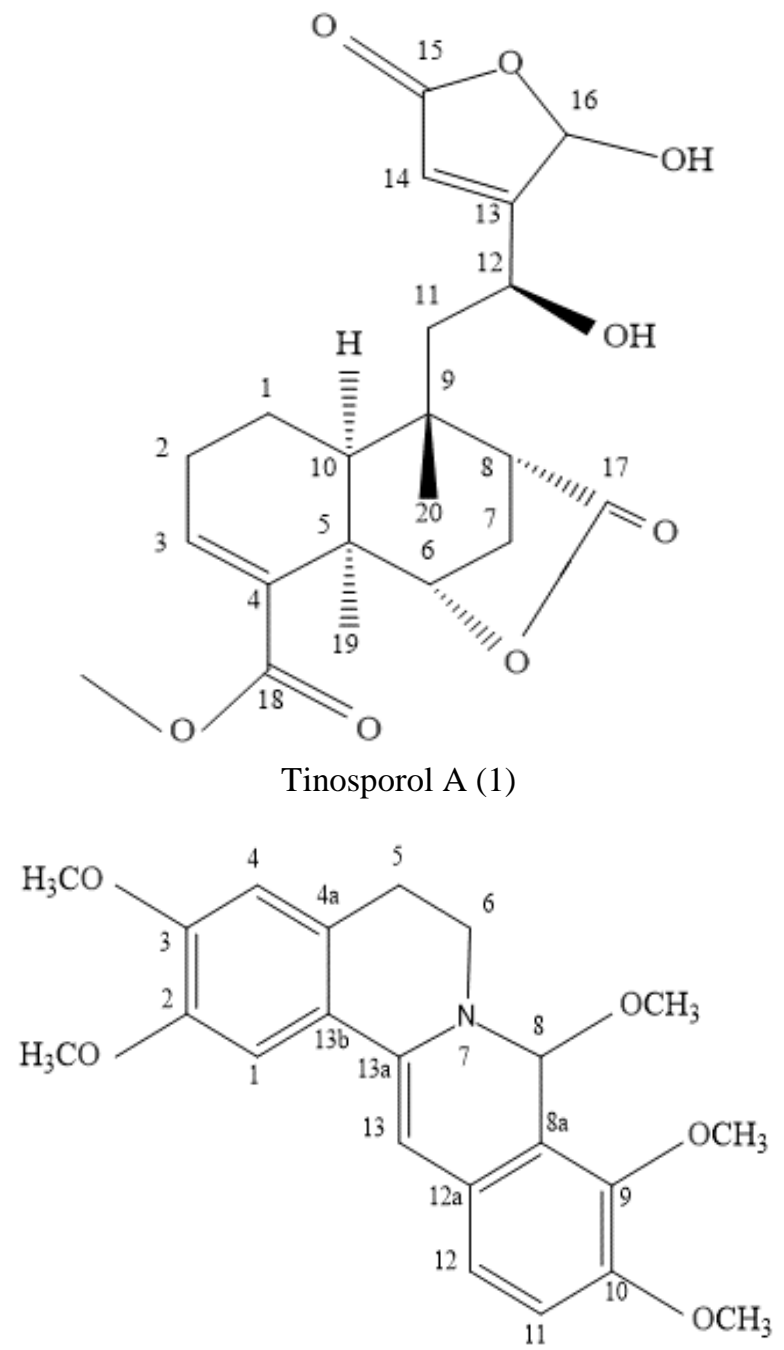

8-Methoxy palmatine (2) 


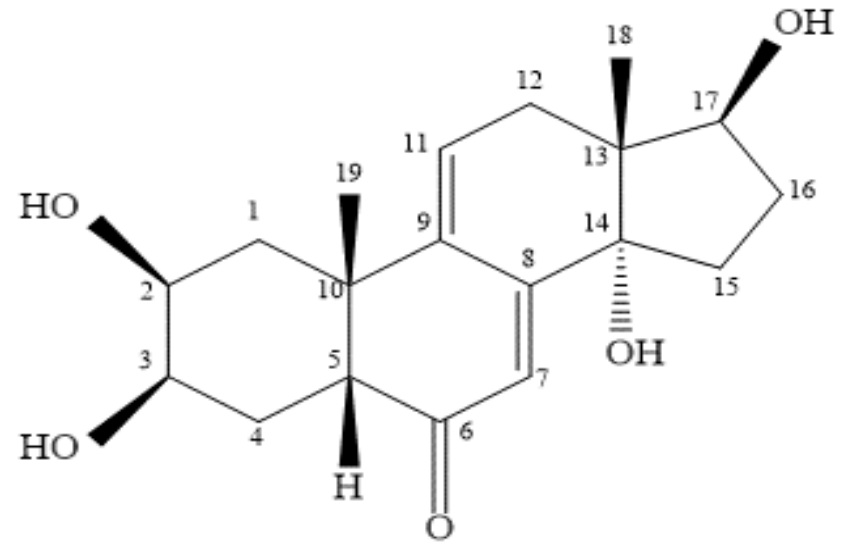

Callecdysterol C (3)

Fig. 1. Structure of isolated compounds.

\section{Antimicrobial Activity Screening}

Antimicrobial activity of crude methanol extract (ME), nhexane (HEX), dichloromethane (DCM), ethyl acetate (EA) and aqueous (AQ) extracts of $T$. crispa was evaluated by disc diffusion method ${ }^{15}$ using $400 \mu \mathrm{g}$ sample per disc in each case. The HEX extract showed significant zone of inhibition against gram positive $S$. aureus $(9 \mathrm{~mm}), S$. boydii $(9 \mathrm{~mm})$ and gram negative $S$. dysenteriae $(9 \mathrm{~mm})$, V. mimicus (8mm) and C. albicans (10mm) and also A. niger $(10 \mathrm{~mm})$ was observed.

\section{Brine shrimp lethality bio assay}

The $\mathrm{LC}_{50}$ values of ME, HEX, DCM, EA and AQ extracts were found to be 57.13, 73.82, 391.21, 424.47, 441.37 and $737.34 \mu \mathrm{g} / \mathrm{mL}$ respectively. $\mathrm{ME}$ and HEX extracts demonstrated moderate lethality whereas DCM, EA and AQ extracts revealed very low activity.

\section{Cytotoxicity assay on cancer and non-cancer cell line}

Cytotoxicity assay of the different extracts of T. crispa was carried out against HeLa cell line (a human cervical carcinoma cell) and Vero cell line (kidney epithelial cells extracted from an African green monkey). $1 \mathrm{mg} / \mathrm{mL}$ sample of different extracts were applied on both HeLa and Vero cell but none of the extracts were found to be cytotoxic against HeLa cell and Vero cell lines.

\section{Total antioxidant capacity (TAC)}

The TAC of different extracts of $T$. crispa extracts was evaluated by the phosphomolybdenum assay method ${ }^{18}$. The TAC was determined and expressed as $\mathrm{mg}$ ascorbic acid equivalents per gram of dry extract using the equation obtained from a standard ascorbic acid calibration curve.The highest TAC was demonstrated by AQ extract (61.61 mg ascorbic acid equivalents/g sample) comparing with other fractions. On the other hand, the lowest TAC was shown by HEX extract (12.11 mg ascorbic acid equivalents/g sample).

\section{Antioxidant Activity}

The antioxidant activity was evaluated in terms of free radical scavenging activity. Among HEX, DCM, ME partitions, DCM fraction showed the highest antioxidant activity $\left(\mathrm{IC}_{50}=54.74 \mu \mathrm{g} / \mathrm{mL}\right)$.

\section{Conclusion}

Tinsporol A, 8-Methoxy palmatine and callecdysterol $\mathrm{C}$ were isolated from the stems of $T$. crispa using different chromatographic separation techniques. The isolated compounds were identified by extensive analysis of their high resolution ${ }^{1} \mathrm{H}-\mathrm{NMR}$ (400 MHz), ${ }^{13} \mathrm{C}-\mathrm{NMR}(100 \mathrm{MHz})$ spectroscopic data. Different types of tests were carried out to evaluate the biological activities of the stems of $T$. crispa. The HEX extract revealed a significant antibacterial activity against gram negative bacteria, C. albicans and antifungal activity against $A$. niger. $\mathrm{ME}$ extract demonstrated highest lethality with $\mathrm{LC}_{50}$ value of 57.13 $\mu \mathrm{g} / \mathrm{mL}$. Different extracts of $T$. crispa stem showed moderate antioxidant activity.

\section{Acknowledgement}

The first author is grateful to the Ministry of Science and Technology, People's Republic of Bangladesh for financial support to this project through NST fellowship program.

\section{References}

1. Sharanabasappa, G.K., M.K. Santosh, D. Shaila, Y.N. Seetharamand I. Sanjeevarao, 2007. Phytochemical studies on Bauhinia racemosa, Bauhinia purpurea Linn. and Hardwickia binate Roxb. E-J. Chem.4, 21-31.

2. Koay, Y. C., and F. Amir, 2013. A review of the secondary metabolites and biological activities of Tinospora crispa (Menispermaceae). Trop. J. Pharm. Res. 12, 641-649.

3. Chung, S. Y., 2011. Studies on the Constituents of the Dry Stem of Tinospora crispa (Lour.) Merr. Masters dissertation, China Medical University 2011.

4. Bisset, N. G., and J. Nwaiwu, 1983. Quaternary alkaloids of Tinospora species. Planta Med. 48, 275-279.

5. Choudhary, M. I., M. Ismail, K. Shaari, A. Abbaskhan, S.A. Sattar, and N.H. Lajis, 2010. cis-Clerodanetype furanoditerpenoids from Tinospora crispa. J. Nat. Prod. 73, 541-547.

6. Cavin, A., K. Hostettmann, W. Dyatmyko, and O. Potterat, 1998. Antioxidant and lipophilic constituents of Tinospora crispa. Planta Med. 64, 393-396.

7. Hipol, R. L. B., M. F. N. M. Cariaga, and R.M. Hipol, 2012. Anti- inflammatory activities of the aqueous extract of the stem of Tinospora crispa (Family: Menispermaceae). J. Nat. Stud. 11, 88-95.

8. Amom, Z., K.F. Azman, N.A. Ismail, Z.M. Shah, and M. S. M. Arshad, 2011. An aqueous extract of Tinospora crispa possesses antioxidative properties and reduces atherosclerosis in hyper cholesterolemic-induced rabbits. J. Food Biochem. 35, 1083-1098.

9. Abood, W. N., I. Fahmi, M.A. Abdulla, and S. Ismail, 2014. Immune-modulatory effect of an isolated fraction from 
Tinospora crispa on intracellular expression of INF-gamma, IL-6 and IL-8. BMC Complement. Altern. Med. 14, 205.

10. Md, H. A., and S. Mohammad, 2011. Antimicrobial, cytotoxicity and antioxidant activity of Tinospora crispa.J. Pharm. Biomed. Sci. 13, 1-4.

11. Bertani, S., G. Bourdy, I. Landau, J.C. Robinson, P. Esterre, and E. Deharo, 2005. Evaluation of French Guiana traditional antimalarial remedies. J. Ethnopharmacol. 98, 45-54.

12. Na, B., Sadikun, A., T. Choon, T. Ying and M. Asmawi, 2005. Aporphine alkaloids isolated from the cardiovascular active fraction of Tinospora crispa. Malays. J. Sci. 24, 161165.

13. Lokman, F. E., H.F. Gu, W.N. Mohamud, M.M. Yusoff, K.L. Chia and C.G. Ostenson, 2013. Antidiabetic effect of oral borapetol B compound, isolated from the plant Tinospora crispa, by stimulating insulin release. Evid. Based Complement. Alternat. Med. 2013, 727602.

14. Edeoga H.O., D.E. Okwu and B.O. Mbaebie, 2005. Phytochemical constituents of some Nigerian medicinal plants. African J. Biotec. 4(7), 685-688.

15. Bayer, C., L.V. Kalm and J.W. Fristrom, 1996. Gene regulation in imaginal disc and salivary gland development during Drosophila metamorphosis. In Metamorphosis: postembryonic reprogramming of gene expression in amphibian and insect cells, Academic Press, San Diego, CA, 321-361.
16. Meyer, B.N., N.R. Ferrigni, J.E. Putnam, L.B. Jacobsen, D.E. Nichols and J.L. McLaughlin, 1982. Brine Shrimp: A Convenient General Bioassay for Active Plant Constituents. Planta Med.45, 31-34.

17. Saroar, F., M. Shoeb, M.N. Islam, M.M. Rhaman, R. Islam and N. Parvin, 2020. Studies of Marine Seaweeds Sargassum flavicans. Asian J. Pharmacogn. 4(1), 52-58.

18. Prieto, P., M. Pineda and M. Aguilar, 1999. Spectrophotometric quantitation of antioxidant capacity through the formation of a phosphomolybdenum complex: specific application to the determination of vitamin E. Analytical Biochem. 269, 337-341.

19. Brand-Williams, W., M.E. Cuvelier and C. Berset, 1995.Use of a Free Radical Method to Evaluate Antioxidant Activity. Food Sci. Technol. 28, 25-30.

20. Gao, Y., Y.F. Niu, F. Wang, F. Wang, W.Y. Xiong and J.K. Liu, 2016. Clerodane Diterpenoids with Anti-hyperglycemic Activity from Tinospora crispa. Nat. Prod. Bioprospect. 6(5), 247-255,

21. Marek, R., P. Sečkářová, D. Hulová, J. Marek, J. Dostál $\square$ and V. Sklenar, 2003. Palmatine and Berberine Isolation Artifacts. J. Nat. Prod. 66, 481-486.

22. Hang, D.T.T., N. T. M. Hang, H.L.T. Anh, N.X. Nhiem, C.T. Hue, P.T. Binh, N.T. Dat, N.H. Nam, P.H. Yen, C.V. Minh, N.V. Hung and P.V. Kiem, 2015. ${ }^{1} \mathrm{H}$ and ${ }^{13} \mathrm{C}$ NMR assignments of new ecdysteroids from Callisia fragrans. Magn. Reson. Chem. May 53(5), 379-82. 